\title{
Temporal trends in the Colonisation of the Pacific: Palaeodemographic Insights
}

\author{
Clare McFadden ${ }^{1}\left(\mathbb{D} \cdot\right.$ Richard Walter $^{2}$ (D) Hallie Buckley ${ }^{3}$ (D) \\ Marc F. Oxenham ${ }^{1,4}$ iD
}

Accepted: 18 January 2021 / Published online: 10 February 2021

(c) The Author(s) 2021

\begin{abstract}
The colonisation of eastern parts of the Pacific Islands was the last phase in the preindustrial expansion of the human species. Given the scale and challenges of the endeavour it is unsurprising that scholars have long been interested in understanding the conditions that drove and supported the exploration and settlement of this vast region. There has been speculation as to the influence of demographic factors, either as drivers or in some way regulating the rate and success of human expansion, but testing this has proven challenging. This study evaluates two hypotheses of population dynamics: the adaptation/resilience hypothesis, which proposes that populations respond to localised environmental conditions and changes in subsistence strategy, technology, differences in pathogen loads, and other events that occur at different times in different places; and the temporal hypothesis, which proposes that populations respond to major events such as climate change that occur in a region at an absolute point in, or over an absolute period of, time (noting that the two hypotheses are not mutually exclusive). Applying new methods for estimating the rate of natural population increase from human skeletal remains, this study utilised 23 samples to evaluate trends in population increase following the human expansion into the region. The results indicate a trend in population growth following colonisation, with initially high population growth, followed by a significant decrease and subsequently an increase in growth rates. The lack of a temporal trend may represent a high degree of heterogeneity in the impacts of climate change on individual archipelagos and islands.
\end{abstract}

Keywords Palaeodemography $\cdot$ Bioarchaeology $\cdot$ Population growth $\cdot$ Pacific archaeology $\cdot$ Population dispersal

Marc F. Oxenham

marc.oxenham@anu.edu.au

Extended author information available on the last page of the article 


\section{Introduction}

The colonisation of eastern parts of the Pacific Islands was the last phase in the preindustrial expansion of the human species. Near Oceania-including the islands of New Guinea, the Bismarck archipelago and parts of the Solomon Islands-was colonised during the Upper Pleistocene some 40,000-30,000 years ago (Fig. 1). In Near Oceania the islands are mainly of continental origin, they are geologically and ecologically complex and diverse, and include many large, inter-visible islands which could be located and settled with minimum levels of sailing knowledge and technology (Green 1991). Around 4000 years ago speakers of Austronesian languages, including members of the Lapita cultural complex, moved through island Southeast Asia and beyond the Solomon Island chain into Remote Oceania. In Remote Oceania the islands are predominantly of volcanic origin, with lower levels of geological diversity and a steep, eastward-declining gradient in biodiversity. Here much more sophisticated navigation skills and sailing technology were required to discover islands, and the establishment of successful colonies was reliant upon a range of new adaptive skills. Yet by 700 years ago virtually every landmass that could support a human colony in Remote Oceania had been discovered and settled. This included the Polynesian triangle from Hawaii in the north to Rapa Nui in the east and Aotearoa (New Zealand) in the south. In addition to the establishment of colonies, trade and communication networks had developed in many parts of Remote Oceania that linked distant communities into dynamic interaction networks (Weisler 1998; Weisler and Walter 2017).

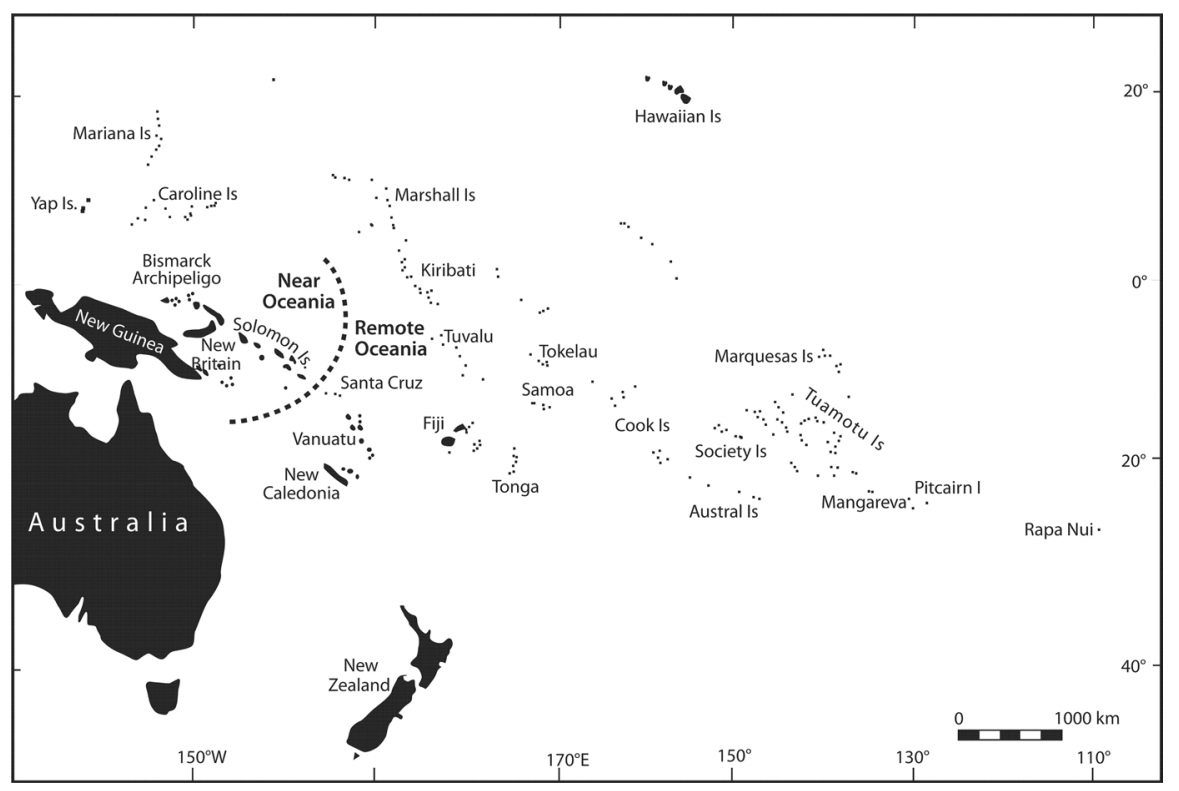

Fig. 1 Pacific map showing near and remote Oceania 
Given the scale and challenges of the endeavour it is unsurprising that since the time of Captain James Cook scholars have been interested in understanding the technological and sociological conditions that drove and supported the exploration and colonisation of the Pacific. One influential model was the strandlooper hypothesis. Introduced by Les Groube (1971), the strandlooper hypothesis argued that the first Lapita settlers may have moved ahead of a later wave of horticulturalists while relying on easily won reef-edge and strandline resources (Davidson and Leach 2001, p. 115) Archaeologists were never confident in the concept of colonisation without horticulture, and in 2000 Kirch (2000, p. 59) set out a strong and compelling argument that the first Lapita communities established horticulture soon after settlement.

It has long been assumed that demographic factors played a major role, either as drivers or in some way regulating the rate and success of human expansion. In his 1984 volume, Kirch set out a theoretical model of post-colonisation demographic change based on a logistic model of growth. He argued that a high rate of population increase was essential to the success of colonising populations. Population levels would grow quickly but would stabilise as the carrying capacity of the environment was approached. The underlying assumption of the model is that many Pacific Islands represent pristine and plentiful environments which could easily sustain enormous population growth in the period immediately following colonisation. Kirch (1984) suggested that an initial rate of natural population increase (RNPI) of $4 \%$ was plausible, based on comparisons with historic data from Pitcairn Island. Testing this model against life tables generated from skeletal data from the Marquesas, Tonga and Hawaii proved problematic, however, due to the poor quality of the dating record.

Clark (1988) agreed fundamentally with Kirch's (1984) model for Pacific population growth, but disputed the extrapolation of data from sites to islands and archipelagos. Further, he cited evidence for significant population density in the region at the time of European contact, which contrasted with Kirch's (1984) model of a stable or declining growth rate in late prehistory. Clark (1988) noted that the rate of growth may have slowed but absolute population numbers continued to increase. Sutton and Molloy (1989) critiqued previous studies, particularly Kirch (1984), suggesting that Pacific palaeodemography was underpinned by erroneous assumptions regarding the growth curve, density dependency and mortality. They argued against Kirch's (1984) view that carrying capacity limited population growth across islands and archipelagos. Observing that the age at death distribution is more sensitive to fertility than mortality, Sutton and Molloy (1989) re-analysed the data from Kirch (1984) as well as some additional datasets and concluded that late prehistoric fertility rates were varied, rather than generally low as island carrying capacity was reached. However, such differences do not necessarily negate the limiting effect of carrying capacity and could indicate variability in the rate at which populations reached the limits of their local environment. Brewis (1995) argued that the demography of each island and archipelago was unique due to differing social and ecological contexts, but that island living also brings consistent challenges that may even transcend time and major events, including European contact. She agreed that prehistoric populations were probably on a path towards equilibrium, before suffering a near-catastrophic collapse at the time of European contact. Nonetheless, she also suggested 
that Pacific populations were likely often in a state of flux with seasonal or irregular environmental pressures impacting on population dynamics. Catastrophic events such as cyclones, droughts, tsunamis, volcanic eruptions and flooding would have impacted upon populations at the local level. This is well documented, for example, in the case of the failure of the breadfruit crop in the Marquesas that devastated local populations between about 1800 and 1803 (Thomas 1990).

In addition to environmental stressors, human action also influenced demographic processes. As Kirch (1984, p. 123) observed, 'Polynesians actively manipulated, modified, and, at times, degraded their island habitats, producing ecological changes which were fraught with major consequences'. Environmental manipulation (Anderson 2002; Burley 1998; Kirch et al. 2004; McCoy and Graves 2010), changes in subsistence (Commendador et al. 2013; Field et al. 2009; Kinaston et al. 2014; Richards et al. 2009), regional differences in pathogen loads, and evidence of illhealth (Kirch 2000; Buckley 2006, 2016; Buckley and Oxenham 2016) are indicated throughout the history of the Pacific Islands. However, it is highly likely that a complex and multidirectional relationship existed between these variables and population dynamics. A possible indirect archaeological indicator of population pressure is the record of fortification construction. Kirch (1984) framed palaeodemography in the context of ecological and cultural stressors but believed that conflict and fortification were a response to increasing populations and subsequent territoriality. This, he argued, was particularly evident on islands and archipelagos where colonisation occurred relatively late, including Hawaii and New Zealand. Field and Lape (2010) reported that peaks in fortification construction in some of the Pacific Islands may have coincided with periods of severe climate conditions associated with the Little Ice Age and El Niño-Southern Oscillation. Although they argued against population pressure as a prime driver in fortification construction, there is clearly a complex relationship with environment, ecology, and sociocultural change, with populations both influencing and being influenced by such factors.

Beyond the theoretical modelling of population dynamics, several researchers have developed demographic models from skeletal sources. This includes analyses by Kirch (1984), Sutton and Molloy (1989), and Pietrusewsky and colleagues (Pietrusewsky et al. 1991, 1994, 1997; Pietrusewsky and Douglas 1994), which have utilised traditional methods (Bocquet-Appel and Masset 1982; Buikstra et al. 1986) that excluded children under five years of age. Others have drawn population inferences from house size and relative frequency (Kirch 1984; Kirch and Rallu 2007), and, most recently, from demographic temporal frequency analyses (dTFA) (Fitzhugh et al. 2016). Utilising newly available skeletal data and tools that incorporate infants and children under five years of age to increase accuracy (McFadden and Oxenham 2018, 2019), this study aims to provide new insights into palaeodemography and human adaptation and resilience in the Pacific Islands using human skeletal remains to reconstruct ancient population dynamics. Two hypotheses are evaluated: the adaptation/resilience hypothesis, and the temporal hypothesis.

The adaptation/resilience hypothesis proposes that populations respond (by way of adaptation or in terms of variable levels of resilience) to localised environmental conditions, including resource availability and constraints, and changes in subsistence strategy, technology, differences in pathogen loads, and other events that 
occur at different times in different places. The most prominent example of this is the transition to, and intensification of, agriculture, which occurred at different points in time around the world but produced a strikingly similar pattern in population dynamics during and after the event. Bocquet-Appel (2002, 2009), BocquetAppel and Naji (2006), and Kohler et al. (2008) used time since intensification of agriculture in Europe, North Africa and North America to evaluate trends in population response. In the Pacific, populations entered new, uninhabited lands and had to adapt and respond to the new ecological conditions they were faced with. This is expected to produce a similar trend in population growth over time, during, and since colonisation of each island and archipelago.

The temporal hypothesis proposes that populations respond to major events such as climate change that occur in a region at an absolute point in, or over an absolute period of, time. If climate change effects within the region had a significant impact on population dynamics, we would expect to observe a temporal trend starting at that point. The effects of climate change on populations have been evaluated in other parts of the world. Using dTFA methods, Tallavaara and Seppä (2012) identified an abrupt decline in population growth in association with late-Holocene cooling in eastern Fennoscandia. Similarly, Tallavaara et al. (2015) observed the effects of climate change on population dynamics between 30,000 and 13,000 years ago in Europe. This was corroborated by Burke and colleagues (2018) who found suitable human habitats were reduced in western Europe during the Last Glacial Maximum.

The two hypotheses are not mutually exclusive, and both may have influenced population dynamics in the Pacific. The results of the two analyses are discussed in the context of the existing data and literature on climate, ecology, infectious disease, subsistence, technology, and social hierarchy and conflict in the region.

\section{Materials}

This study utilised published data for twenty samples and the authors' own data for three samples (Table 1). Data from Pain Haka on Flores - though outside of Oceania-were included due to the relative proximity to Melanesia. Whilst every effort has been made to ensure the reliability and accuracy of the data included in this study, it is pertinent to note the limitations and caveats that apply to both individual samples and all skeletal samples more broadly.

\section{Age Estimation}

Where possible, unit records were reviewed to determine the number of subadults aged 0-14 years and the total number of individuals. In some cases, unit records were not published, and the reported numbers were utilised. If the reported age categories overlapped the 15 years of age demarcation, and unit records were not provided, the number of individuals aged under 15 years was estimated as a proportion of the age category (for example, if the age category was 12-16 years inclusive, $60 \%$ of individuals in that age group were estimated to be under 15 years of age). As per 


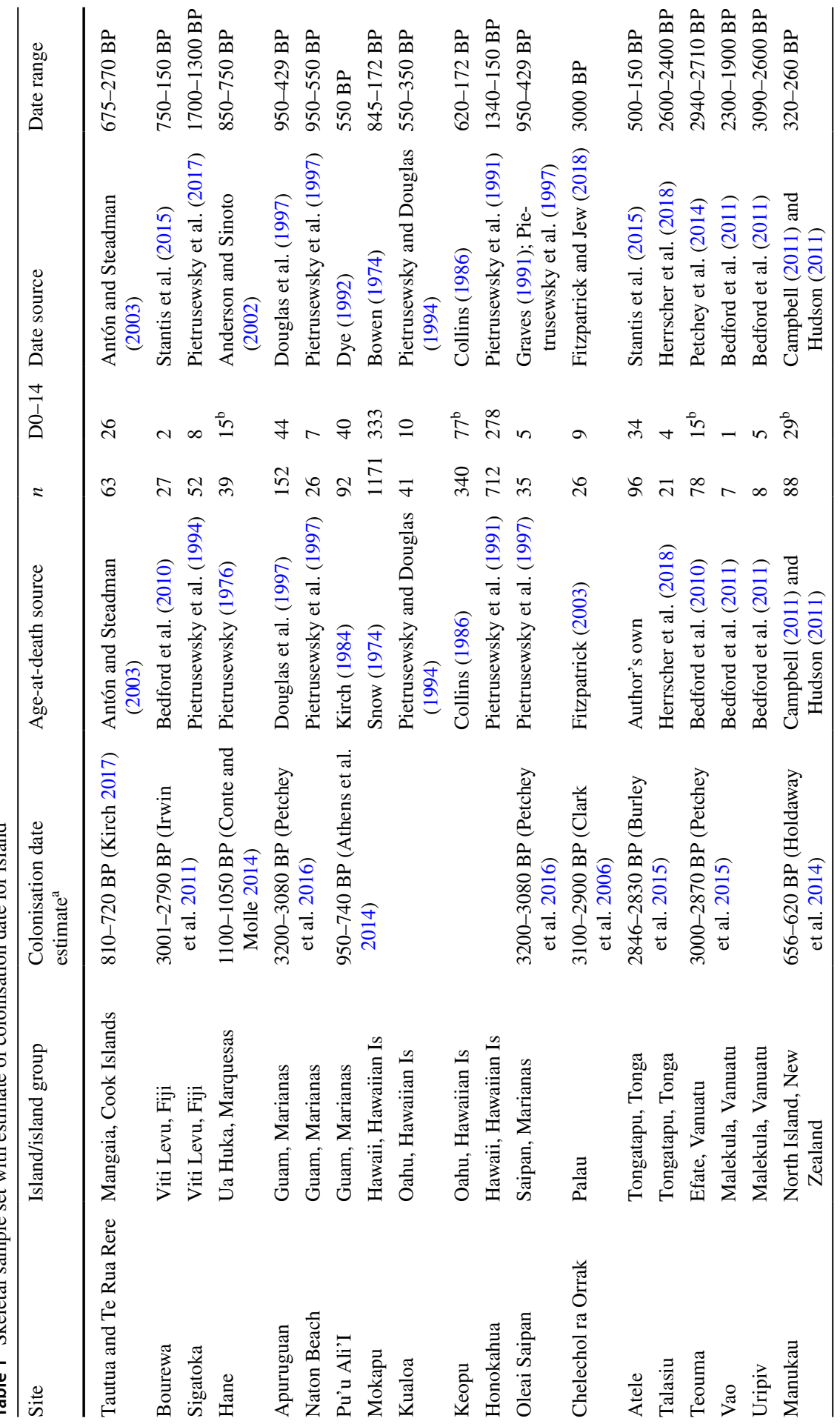




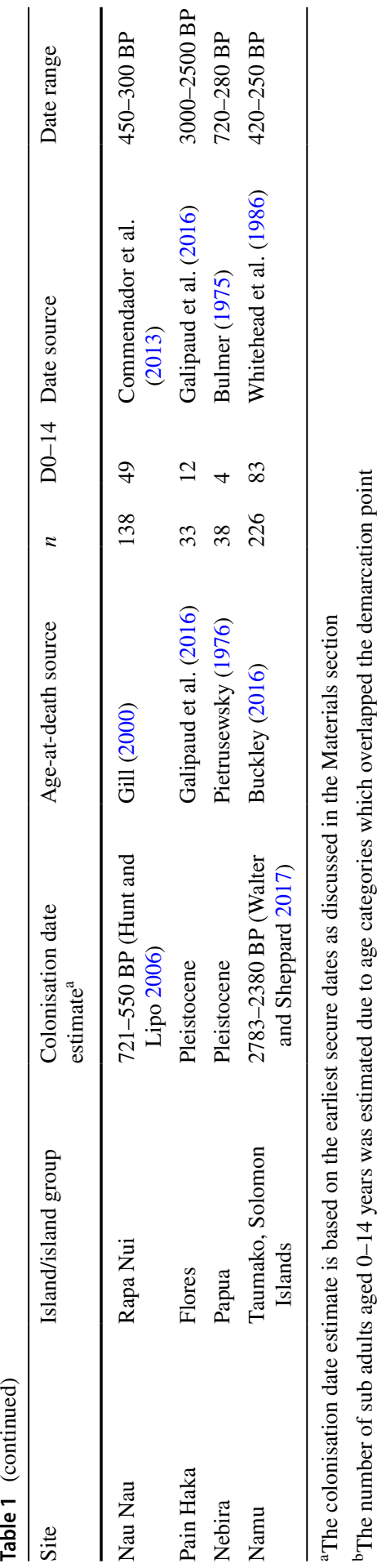


McFadden and Oxenham (2019), the error involved in this is very unlikely to have any meaningful impact on the estimated RNPI.

\section{Sample Representativeness}

The earliest large cemetery assemblage from New Zealand is from Wairau Bar, which dates to the early fourteenth century (Jacomb et al. 2014). Unfortunately, the sample was excluded due to the absence of any subadults, indicating significant bias as observed by Buckley et al. (2010). Teouma has been included in the study due to the presence of a significant number of infants (including many pre-term infants), however, these data are still likely skewed by the almost complete absence of children. This is suspected to be the result of this cohort being interred elsewhere.

It is possible that sample bias has occurred at other sites included in this study. Traditionally, skeletal samples with low infant and subadult representation have broadly been considered to be misrepresentative of the population they derive from due to differential deposition, poor preservation, or recovery bias. In this study, only samples where infants are not represented at all have been excluded. It is also important to note that the existence of some samples with low proportions of infants and subadults is necessary if we accept that there were periods of population decline in prehistory. Uripiv and Vao are notably small samples and may not be representative of the populations from which they are derived. The sample for Mangaia represents two pre-contact sites, Tautua and Te Rua Rere, as census data are reported by period only (Antón and Steadman 2003) and therefore it was not possible to extract data by individual site. These are the only two sites that are reported to cover the precontact period, and it is notable that Tautua only contains four individuals (Antón and Steadman 2003). As such, the mixing of the samples is unlikely to significantly impact the RNPI, which is more representative of Te Rua Rere than Tautua.

\section{Dates for Island Settlement}

The estimate for date of settlement of each island or island group is conservative. We have based these estimates on the earliest radiocarbon dates reported in the literature that appear to be from a secure stratigraphic context and on identified shortlived species. It is always assumed that these dates will always post-date the actual colonisation date by some unknown time. Pinpointing the colonisation of Oceanic islands is problematic, but archaeologists are working towards resolution. A major move in the 1990s towards a more robust application and interpretation of radiocarbon dating (Spriggs and Anderson 1993) resulted in an upward revision of the sequence for most of Polynesia. In East Polynesia, there was a move towards proxy dating - the evaluation of presumed anthropogenic landscape modifications in order to narrow the gap between the early radiocarbon samples from cultural horizons, and the actual settlement date (Kirch et al. 1992; McWethy et al. 2014; Wilmshurst et al. 2008). So far, the gap appears to remain short-as evidenced, for example, with the dating of moa extinction. It is well understood that a wave of avian extinctions immediately followed human arrival throughout Polynesia (Steadman 1995, 
1997). The most iconic example of this is the extinction of the giant, flightless moa (Aves, Dinornithiformes) in New Zealand. For many years archaeologists assumed that extinction followed centuries of hunting (Anderson 1984; Davidson 1984). It is now understood that extinction was extremely rapid, occurring in possibly less than a century - two or perhaps three human generations (Holdaway and Jacomb 2000; Perry et al. 2014). It seems unwise, then, to assume a long gap (centuries for example) between the age of a deposit containing now-extinct or extirpated species and the time of first human settlement on an Oceanic island.

\section{Sample Dates}

Similarly, the dates for each sample suffer from the typical uncertainties associated with archaeological dating. The sample with the lowest-confidence date estimate is Mokapu. From the absence of any European material, the site is known to pre-date European contact (Bowen 1974); however, even several decades after the original excavation, little more is known about its chronology. This places the age of Mokapu at any point between the settlement of Hawaii in 950-740 BP (Athens et al. 2014) and European contact in 1778 (or $172 \mathrm{BP}$ ). In this study, the midpoint for settlement (845 BP) and the known date of European contact (172 BP) have been used to determine the sample date midpoint (508.5 BP).

\section{Island Diversity}

To account for variations in geographic and ecological diversity, we have adopted the simple classification of island type used by Kirch (2017). In this system, islands are divided into four groups:

1. Island arcs or continental islands are the oldest island forms, with complex geological histories and, typically, large areas of arable land. They are concentrated in Near Oceania.

2. Volcanic high islands vary considerably in size but are sufficiently elevated to induce windward precipitation. They are typically basaltic but with a highly simplified geological history compared to continental islands. Tropical volcanic high islands have coral reefs and may subside through time to form atolls or submerged reefs.

3. Makatea islands are uplifted coral platforms that may, or may not, have a central volcanic core. Freshwater and arable soils are in shorter supply than on volcanic high islands.

4. Atolls are low platforms of sand built on coral foundations which are frequently arranged in a ring around a central lagoon. Atolls have no standing water sources, no stone other than coral, and only thin, patchy topsoils. Table 2 shows island form and size for each island that provided a sample set. Island size is included here as a rough proxy for relative carrying capacity. 
Table 2 Island size and form [following Kirch (2017)] for each island that provided a skeletal sample set

\begin{tabular}{|c|c|c|c|}
\hline Site, Island & Island form & $\begin{array}{l}\text { Island land area } \\
\left(\mathrm{km}^{2}\right)\end{array}$ & $\begin{array}{l}\text { Estimate of } \\
\text { arable land } \\
\left(\mathrm{km}^{2}\right)\end{array}$ \\
\hline $\begin{array}{l}\text { Tautua and Te Rua Rere } \\
\text { Mangaia }\end{array}$ & Makatea & 52 & $20^{\mathrm{a}}$ \\
\hline $\begin{array}{l}\text { Bourewa, Sigatoka } \\
\text { Viti Levu }\end{array}$ & Island arc & 10,388 & $935^{\mathrm{b}}$ \\
\hline Hane, Ua Huka & Volcanic high island & 83 & $42^{\mathrm{c}}$ \\
\hline $\begin{array}{l}\text { Apuruguan, Naton Beach } \\
\text { Guam }\end{array}$ & Makatea & 544 & $10^{\mathrm{b}}$ \\
\hline $\begin{array}{l}\text { Pu'u Ali’I, Keopu } \\
\text { Hawaii }\end{array}$ & Volcanic high island & 10,430 & $1048^{c}$ \\
\hline $\begin{array}{l}\text { Mokapu, Kualoa } \\
\text { Oahu }\end{array}$ & Volcanic high island & 1545 & $150^{\mathrm{c}}$ \\
\hline Honokahua, Maui & Volcanic high island & 1883 & $183^{\mathrm{c}}$ \\
\hline $\begin{array}{l}\text { Oleai } \\
\text { Saipan }\end{array}$ & Makatea & 115 & $3^{b}$ \\
\hline Chalechol ra Orrak, Palau & Makatea & 459 & $10^{\mathrm{b}}$ \\
\hline Atele, Tongatapu & Makatea & 260 & $182^{\mathrm{c}}$ \\
\hline Teouma, Efate & Volcanic high island & 900 & $15^{\mathrm{b}}$ \\
\hline $\begin{array}{l}\text { Vao and Uripriv } \\
\text { Malekula }\end{array}$ & Volcanic high island & 2041 & $33^{\mathrm{b}}$ \\
\hline Manukau, North Island, New Zealand & Island arc & 113,729 & $4549^{c}$ \\
\hline Nau Nau, Rapa Nui & Volcanic high island & 164 & $106^{\mathrm{c}}$ \\
\hline $\begin{array}{l}\text { Pain Haka } \\
\text { Flores }\end{array}$ & Volcanic high island & 13,540 & $1760^{\mathrm{b}}$ \\
\hline $\begin{array}{l}\text { Nebira } \\
\text { PNG }\end{array}$ & Island arc & 462,860 & $3240^{\mathrm{b}}$ \\
\hline Namu, Taumako & Volcanic high island & 10 & $0.1^{\mathrm{b}}$ \\
\hline
\end{tabular}

Basis of estimates

${ }^{\mathrm{a}}$ Kirch et al. (1995, p. 49)

${ }^{\mathrm{b}}$ CIA World Factbook-\% of arable land for country used to calculate figure [this source used when figures not available in Kirch (1984)]

${ }^{\mathrm{c}}$ Kirch (1984, p. 98, table 10). Note: the total land area given for Mangaia in this table was anomalous, so Kirch et al. (1995) used instead

\section{Methods}

The methods of McFadden and Oxenham (2018) were used to estimate the rate of natural population increase (RNPI). The method is based on the linear relationship between the ratio of juveniles to the total population (individuals who died aged 0-14 years divided by the total sample size, or D0-14/D ratio) and the RNPI in modern human populations. The D0-14/D ratios for each sample and equation produced by McFadden and Oxenham (2018) were used to derive the RNPI estimates. In order to evaluate the trend in population growth following colonisation 
and the potential impacts of carrying capacity, adaptation, and technological and social change, the rates of increase for each sample were plotted based on the midpoint of the time elapsed since colonisation (see Tables 1 and 3) of each island or island group (Fig. 2). This follows previous studies where the time since agricultural introduction or intensification has been analysed (Bocquet-Appel 2002, 2009; Bocquet-Appel and Naji 2006; Kohler et al. 2008). Additionally, the RNPI estimates were plotted by years before present (BP) to evaluate the impacts of climate change, which occurs on an absolute, rather than relative, temporal scale (Fig. 3). The data from Nebira and Pain Haka were included in the temporal (years BP) analysis but were excluded from the years-since-colonisation analysis, since they were associated with islands or archipelagos that had very early colonisation, in some cases pre-dating modern humans. This meant these samples could not be compared based on time since colonisation.

Table 3 D0-14/D ratio, rate of natural population increase, mid-point of years since colonisation, and mid-point of years BP for each site

\begin{tabular}{|c|c|c|c|c|c|c|}
\hline Site & $\begin{array}{l}\text { Island/archi- } \\
\text { pelago }\end{array}$ & $n$ & D0-14/D ratio & RNPI \% & $\begin{array}{l}\text { Mid-point years } \\
\text { since colonisa- } \\
\text { tion }\end{array}$ & $\begin{array}{l}\text { Mid-point years } \\
\text { BP for burial site }\end{array}$ \\
\hline Mangaia & Cook Islands & 63 & 0.41 & 2.54 & 292.5 & 472.5 \\
\hline Bourewa & Fiji & 27 & 0.07 & -0.86 & 2445.5 & 450 \\
\hline Sigatoka & Fiji & 52 & 0.15 & -0.06 & 1395.5 & 1500 \\
\hline Hane & Marquesas & 39 & 0.38 & 2.26 & 275 & 800 \\
\hline Apuruguan & Guam & 152 & 0.29 & 1.30 & 2450.5 & 689.5 \\
\hline Naton Beach & Guam & 26 & 0.27 & 1.10 & 2390 & 750 \\
\hline Pu'u Ali'I & Hawaii & 92 & 0.43 & 2.76 & 295 & 550 \\
\hline Mokapu & Hawaii & 1171 & 0.28 & 1.25 & 336.5 & 508.5 \\
\hline Kualoa & Hawaii & 41 & 0.24 & 0.84 & 395 & 450 \\
\hline Keopu & Hawaii & 340 & 0.23 & 0.67 & 449 & 396 \\
\hline Honokahua & Hawaii & 712 & 0.39 & 2.31 & 100 & 745 \\
\hline Oleai Saipan & Marianas & 35 & 0.14 & -0.17 & 2450.5 & 689.5 \\
\hline $\begin{array}{l}\text { Chelechol ra } \\
\text { Orrak }\end{array}$ & Palau & 26 & 0.35 & 1.87 & 0 & 3000 \\
\hline $\begin{array}{l}\text { Tongatapu / } \\
\text { Atele }\end{array}$ & Tonga & 96 & 0.35 & 1.95 & 2513 & 325 \\
\hline Talasiu & Tonga & 21 & 0.19 & 0.31 & 338 & 2500 \\
\hline Teouma & Vanuatu & 78 & 0.19 & 0.32 & 110 & 2825 \\
\hline Vao & Vanuatu & 7 & 0.14 & -0.17 & 835 & 2100 \\
\hline Uripiv & Vanuatu & 8 & 0.63 & 4.68 & 90 & 2845 \\
\hline Manukau & New Zealand & 88 & 0.33 & 1.71 & 348 & 290 \\
\hline Nau Nau & Rapa Nui & 138 & 0.36 & 1.96 & 375 & 375 \\
\hline Taumako & Solomon & 226 & 0.37 & 2.09 & 2246.5 & 335 \\
\hline Pain Haka & Flores & 33 & 0.36 & 2.05 & n.a & 2750 \\
\hline Nebira & Papua & 38 & 0.11 & -0.55 & n.a & 500 \\
\hline
\end{tabular}




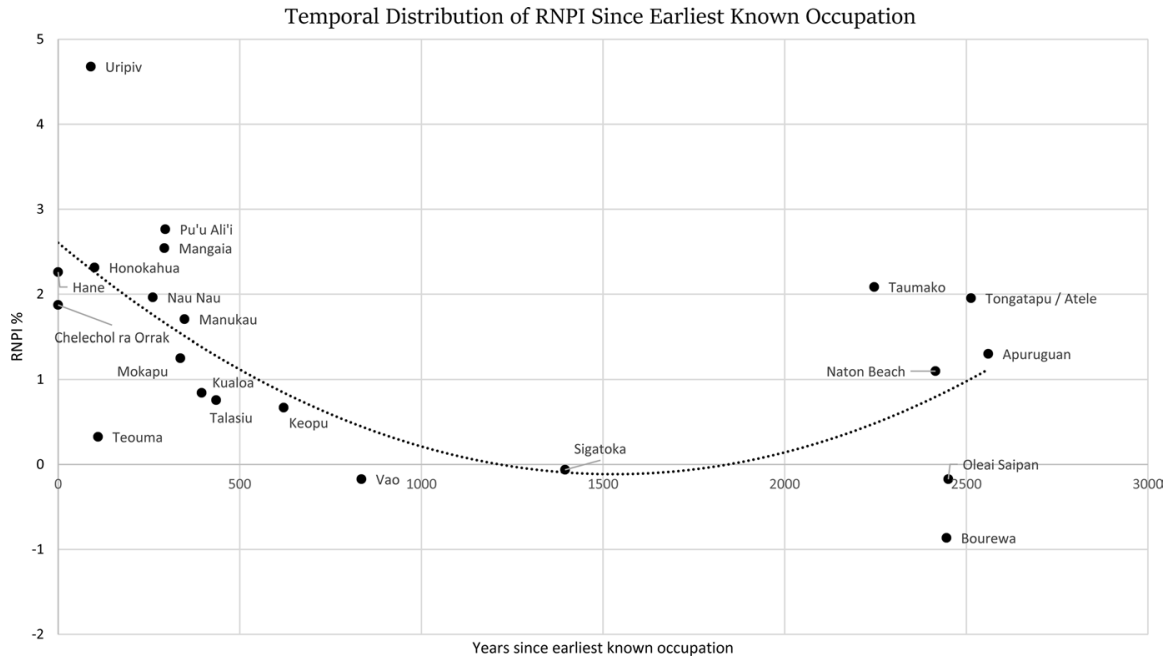

Fig. 2 Distribution of sites by years since earliest known occupation date

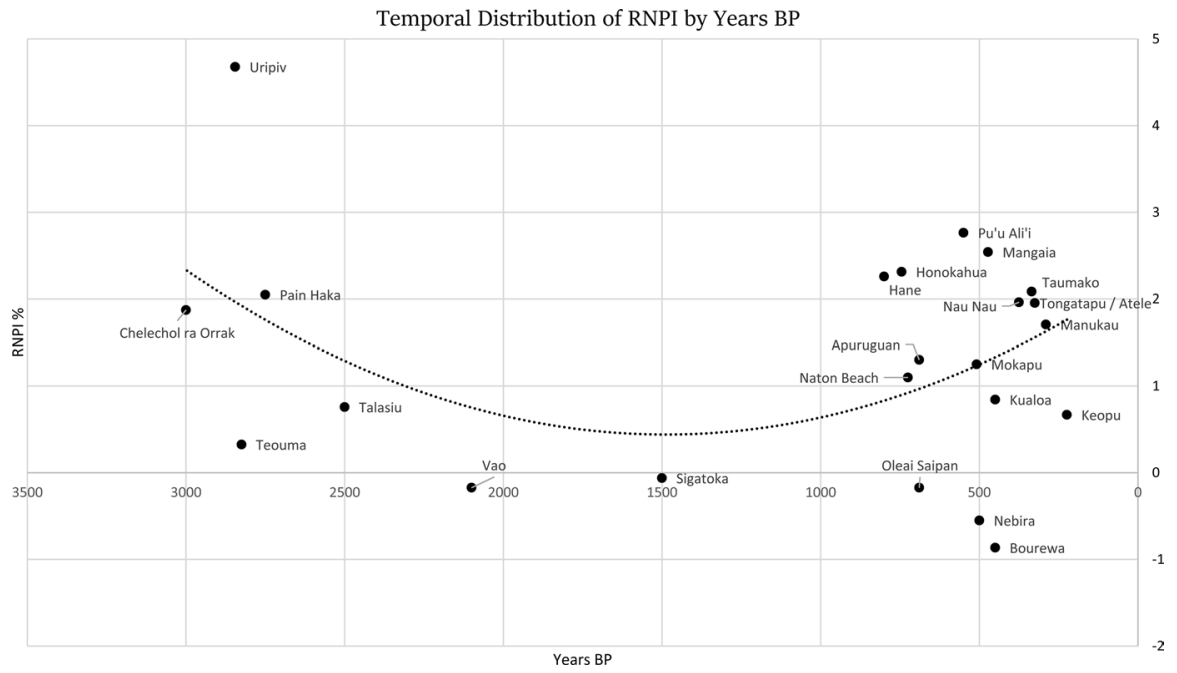

Fig. 3 Distribution of sites by years before present (BP)

In order to evaluate trends in the time since colonisation, and based on absolute chronology, the mid-point of the date range for colonisation and the mid-point of the years BP for the burial site were calculated. To plot the RNPI by years since colonisation, the mid-point of the years BP for the burial site was subtracted from the mid-point of the date range for colonisation, to give an estimate of years since colonisation. To plot the absolute chronological trend, the raw mid-point of years BP for each burial site was used. Linear and polynomial models were applied to determine the best fit based on significance and correlation. 
The D0-14/D ratio has been shown to be unaffected by migration rates of between $-2.82 \%$ and $1.76 \%$; however, its resilience to migration rates greater than this is unknown (McFadden and Oxenham 2018). In the study area, it is unlikely that migration events following the first wave of colonisation had a significant effect on population dynamics over the long term. Some islands (such as Rapa Nui) and some archipelagos (such as Hawaii and New Zealand) were probably settled once, or in a series of landfalls over a very short period. In all the islands and island groups apart from Rapa Nui, communication networks linked communities within and beyond the local archipelagos. There would have been regular movements of people, ideas and items of exchange within communication networks, but for the most part, there is little archaeological evidence for large-scale, post-colonisation migration, or population movement or replacement. The possible exceptions to this would be coastal Papua where both oral tradition (Neumann 1992) and archaeology suggest some large-scale movements of different culture groups over recent centuries. But again, this is unlikely to have had an impact on population dynamics within the time frames and scale of resolution of the current study.

\section{Results}

The D0-14/D ratio, calculated RNPI, the mid-point of the estimated years BP, and the mid-point of estimated years since colonisation for each site are provided in Table 3. The estimated RNPI ranged from $-0.86 \%$ for Bourewa to $4.68 \%$ for Uripiv. Plotting the data from Table 3 using a second order polynomial, the years since colonisation trend produced a moderate trend of $\mathrm{r}^{2}=0.32(\mathrm{p}<0.05$, Durbin-Watson test within normal range), while the temporal trend showed greater variability $\left(r^{2}=0.14\right.$, $\mathrm{p}>0.05$, Durbin-Watson test within normal range).

\section{Discussion}

\section{Palaeodemographic Findings}

Our analyses produced a stronger and clearer trend for the adaptation/resilience hypothesis. High population growth at the time of, and immediately following, colonisation was observed for the majority of the islands and archipelagos included in this study. This was followed by a decline in growth and even, in some cases, a possible decline in populations (negative growth rates). Subsequently, it appears that Pacific populations generally began to increase again up until European contact, although this is not the case for all islands and archipelagos. For Hawaii, the five samples in this study are suggestive of population stabilisation over time with relatively slower growth in the late pre-contact period, consistent with early estimates by Kirch (1984). A similar trend was observed for Vanuatu, although there were no late pre-contact samples available for this study. The Fijian samples indicated population decline but interpretations are limited by the small number of samples $(n=2)$. The overall trend by years since colonisation closely mirrors that reported for Southeast 
Asian sites from the Neolithic to the Iron Age (McFadden et al. 2018), however, it is notable that the Pacific samples of similar antiquity show greater spatial homogeneity (where there are sufficient data to evaluate this) in contrast to observations from the Southeast Asian study. The temporal trend of years before present produced a far weaker trend and demonstrated significant variability from approximately 800 BP until European contact.

It is notable that a number of previous authors have speculated that there may have been very low growth rates [0.005 proposed by Kirch (1984) and 0.00875 by Brewis et al. (1990)] for early populations in the Pacific. As per McFadden et al. (2018), we argue that such low growth rates over long periods of time are to be expected and reflect the oscillating nature of population dynamics. We believe our method identifies some of these oscillations, allowing us to examine the conditions associated with the various peaks and troughs in population growth. It is also important to note that such low growth rates would involve an extraordinary level of self-regulation. Equally, we do not propose that these growth rates held steady over hundreds or thousands of years, but that these rates are representative of the samples from which they derive, for the period over which the sample was amassed [see McFadden et al. (2018) for further explanation of various oscillating models of growth].

\section{Years Since Colonisation Trend}

The trend in years since colonisation (Fig. 2) allows us to evaluate the adaptation/ resilience hypothesis, specifically the localised conditions that may have had an impact on populations as they colonised previously uninhabited islands. These factors include dietary and subsistence adaptation, pathogen loads, resource availability (including faunal extinctions), and carrying capacity. As previously noted, if we assume that populations may have a similar response to the pressures of moving into a new environment, then we may anticipate a similar population response in the period following colonisation of an island. As this event takes place at different times in different locations, a trend in relative time since colonisation is supportive of this theory. Observations from the Neolithic Demographic Transition (BocquetAppel 2002; Bocquet-Appel and Naji 2006) which was also a multifactorial event with a range of impacts on populations, set a precedent for such a response.

\section{Diet, Subsistence, and Adaptation}

The islands of Oceania have a high level of terrestrial biodiversity and are quite varied in their potential for human production systems (Cox and Banack 1991; Kirch 2000; Kirch and Hunt 1997). This diversity has heavily influenced cultural and political development in island societies (Kirch 1984; Kirch and Hunt 1997; Sahlins 1958). Pacific agricultural systems were once thought to have been transferred from primary centres of domestication and production in Southeast Asia. It is now known that while many plants and animals of southeast Asian origin were imported into Island Melanesia, Pacific production systems also incorporate a suite of indigenous 
domesticates. These include Taro, some bananas and the Canarium nut tree (Manner and Thaman 2013, p. 341). Melanesia, and specifically the New Guinea Highlands, is now recognised as one of the world centres of domestication with the first production systems, based on local domesticates, appearing in the early Holocene (Denham 2003; see also articles in Golson et al. 2017), and direct evidence of banana has been found in the dental calculus of the Teouma people (Tromp et al. 2020). The successful incorporation of exotic and indigenous plants and animals into a tropical-Pacific adapted production suite was central to the colonisation of Oceania-especially Remote Oceania, with its more diminished terrestrial biodiversity (Tromp et al. 2020). Although direct evidence for early production systems is uncommon, there is strong evidence that the first settlers introduced agriculture in Tonga (Burley et al. 2020), Mangaia (Cook Islands: Kirch et al. 1995) and New Zealand (Barber 2004), and, as with Lapita, it is extremely unlikely that any Polynesian island was settled by non-horticultural communities.

Hawaii has some of the best described agricultural systems where horticulture and the production of surplus underlay the formation of one of Polynesia's most complex chiefdom systems (Kirch 2010). Kirch et al. (2004) suggested that the persistence of agricultural activities under less than ideal ecological conditions in Hawaii could be indicative of demographic and economic pressures. There is evidence that the impact of agriculture on the Hawaiian ecosystem was severe in places, with intensive land use and manipulation resulting in degradation of lowland areas, changes to vegetation, and extinctions (Kirch 1984). These activities had a range of consequences including increased soil erosion. Broadly, deforestation and erosion have been observed throughout Oceania in two patterns: late-starting (in terms of time since colonisation) and slow changes in the larger western islands, and quicker, more substantial changes in the eastern islands (Anderson 2002).

A major consequence of subsistence strategies, agriculture, and introduction of new species is the extinction of native wildlife. Using wetland coring data and bones of extinct birds from the 'Ewa Plain, Athens et al. (2002) reported that avian extinctions occurred within the period immediately following colonisation of Hawaii but were likely partly due to the destruction of native lowland forests by the introduced Rattus exulans. Using a systematic review of extinction data for Hawaii, Boyer (2008) found that large and ground-nesting birds were the most susceptible to extinction in the period following colonisation, and suggested that competition with and destruction by the common rat, coupled with land clearing for agricultural purposes, caused the extinctions. Kirch (1996) reported the extinction of at least 13 native birds on the island of Mangaia, Cook Islands, following colonisation, and similarly argued for combined causes. Steadman (1995, 1997, 2006) has demonstrated that extinctions following colonisation have been far-reaching, occurring throughout Polynesia, Micronesia and Melanesia. The total loss across Oceania's major islands is in the order of 8000 species, with predation by humans and introduced fauna, and habitat loss through land use and manipulation, suggested as the major culprits. Terrestrial wildlife was also impacted, particularly frogs, crocodiles, lizards and tortoises (Anderson 2002).

As observed during the transition to and intensification of agriculture, changes in diet and subsistence strategies can have major impacts on population growth. 
Depletion, and extinction, of certain species through consumption and possible behavioural shifts may represent a period of adaptation to the local environment. As the new inhabitants exhausted some resources, but equally became more familiar with those in abundance, changes in species selection may have occurred. The subsequent implementation of horticultural and agricultural practices represents a shift in economy and the ability to sustain larger populations. These factors may have contributed to the trend observed in Fig. 2.

There is a multitude of evidence for dietary change following colonisation in the Pacific Islands. Swift et al. (2018) reported on changes in diet composition as evidenced by isotope analyses from commensal rats. While Richards et al. (2009) found the diet of the Hanamiai population in the Marquesas Islands to be largely terrestrial, Swift et al. (2018) identified a decreasingly terrestrial and increasingly marine diet at sites in the Marquesas, with the most significant changes occurring between 1200 and 1400 AD. A similar pattern was observed in Fiji between 1000 and 1200 AD, while Mangareva, in French Polynesia, showed a consistent marine focus (Swift et al. 2018). At Teouma, the diet was found to include a mixture of marine and terrestrial animals (Kinaston et al. 2014), and Valentin et al. (2014) reported a decline in consumption of high trophic level foods approximately 500 years after colonisation, potentially indicative of a reduction in native animal resources through extinctions, other adaptations to environmental and climatic changes, or possibly social stratification. Commendador et al. (2013) found that the Rapa Nui diet was predominantly terrestrial, with a possible slight increase in marine consumption over time. Morrison and Hunt (2007) analysed shellfish assemblages from three stratigraphic and chronological zones from Nu'alolo Kai, Kaua'i, and found a shift over time from large shellfish to smaller, more abundant shellfish and more diverse taxa. This, they argued, could indicate foraging intensification and resource depletion forcing a change in foraging strategy. There is also substantial diet variability between coastal and inland sites. Field et al. (2009) identified an increase in terrestrial sources between 2700 and $760 \mathrm{BP}$, but the retention of a predominantly marine diet. At Sigatoka, diet reportedly remained stable over 900 years, with a terrestrial focus. Field et al. (2009) concluded that larger islands likely had a greater terrestrial resource base, permitting faster incorporation into the diet. The research to date implicates a number of causes for dietary changes, including exhaustion of resources, climate change, and intentional shift in strategy.

Finally, it is perhaps worthwhile mentioning cannibalism as a potential source of protein, given the considerable literature on the topic (e.g., see Arens 1979; Lindenbaum 2004; Obeyesekere 2005; Taylor 2004, 2018 for changing views on cannibalism over time). Archaeologically, evidence for Pacific cannibalism has either been refuted, for example by Scott et al. (2010) at Teouma, Vanuatu and by Degusta (2000) on Vunda, Fiji; been seen as equivocal, for example by Cochrane et al. (2004) and Pietrusewsky et al. (2007) at Qaranicagi, Fiji; or argued to have occurred-for instance, Degusta (1999) interpreted the treatment of human remains from Navatu, Fiji as consistent with cannibalism. As to the role of cannibalism in terms of economic or dietary considerations, evidence is scant. Jennings (2011), following a close scrutiny of ethnographic evidence, argues for its limited occurrence in New Zealand and only with respect to interpersonal conflict. If this is anything to go by, 
its role in the Pacific was perhaps more ritual than economic and as such, would have made a limited contribution (if any) to subsistence practices.

\section{Local Ecology and Carrying Capacity}

While adaptation to local conditions would have been essential to survival, there are conditions outside of human control that may have influenced population growth. Availability of potable water and suitability of conditions for horticulture would have had major implications for subsistence strategy (e.g., Kirch 2007), as would the extent of available arable land.

The carrying capacity growth model, or logistic growth model, states that populations grow exponentially until they reach an upper limit, known as carrying capacity or $\mathrm{K}$, at which point growth plateaus. The model has been used to explain growth in a range of biological scenarios, but for human population growth it has been hypothesised that populations living in regions with restricted natural resources (including islands, and migration into previously uninhabited areas) will grow exponentially to the point that the resource limits are reached (i.e. population consumption and resources are at equilibrium), then growth will cease and the population size will stabilise before resources are irreparably diminished (Diamond1977). Tuljapurkar et al. (2007) noted that there are challenges in applying a carrying capacity model, as it is highly dependent on contextual factors (including ecology, technology, and behaviour) which are often difficult to assess or determine from the archaeological record. There are further complexities, including Kirch and Rallu's (2007) observation that human populations rarely achieve maximum growth, and if so, do not sustain it for any significant period of time. Whilst elusive, many researchers believe that carrying capacity played a significant role in the palaeodemography of the Pacific (Kirch1984; Kirch and Rallu 2007; Athens et al. 2007; Leppard 2016). In contrast, Sutton and Molloy (1989) were highly critical of what they considered the misuse of an outdated demographic model. Importantly, they note that increase in warfare, agriculture and social complexity do not necessarily reflect population stress, citing Boserupian theory in support (Sutton and Molloy1989).

\section{Disease Ecology}

The potential impact of pathogens such as malaria on human settlement and population growth in the Pacific islands was first argued by Groube in 1993. The intense endemicity of malaria in archipelagos west of and including Vanuatu has long been recognised as having a negative impact on human health in this region (Lambert 1941; Sayers 1943) and its complete absence in Polynesia is posited as one factor allowing for the population sizes noted at European contact (Groube 1993; Kirch 2000). A possible association between the presence of malaria in the west and its absence in Polynesia has also been noted in the skeletal record in terms of indicators of non-specific stress (Buckley 2006). Malaria and other pathogens exhibit a decrease in intensity and number similar to that shown by the biodiversity of plant and animal resources available to colonising groups; this may have influenced 
population growth in the past but it is difficult to test directly as many such pathogens do not leave diagnostic changes in the skeleton. However, the presence of nutritional deficiency diseases such as scurvy in young infants at Teouma (Buckley et al. 2014) and probably 'Atele, Tongatapu (Buckley 2000), attests to the influence of disease on maternal and infant health in these populations. Indeed, skeletal pathology diagnostic of scurvy in foetal individuals at Teouma demonstrates the fragility of island environments and transitioning subsistence strategies for colonising populations.

\section{Temporal Trend: Climate Change and the Little Ice Age}

The trend in years BP permits us to evaluate the temporal hypothesis, specifically the potential effects of events that occur at absolute points in time. The Little Ice Age (LIA) is believed to have impacted upon climate in the Pacific from approximately 850 to 200 BP. Evaluating the temporal trend (Fig. 3) in light of this, the LIA may be implicated during this period of greater palaeodemographic variability and even population volatility. If the LIA impacted upon islands and archipelagos in different ways, this may explain the variability in growth rates. Nunn (2007) argued that the LIA, or 'AD 1300 Event', caused widespread disruption to populations in the Pacific islands. Around 1350 AD, sea levels fell 50-80 cm and the temperature fell by approximately $1.4 \mathrm{C}$ in New Zealand (Nunn 2007), and 0.56 in the New Zealand alps (Lorrey et al. 2014), and possibly more through the northern parts of the Pacific. Prior to this climatic event, humans are thought to have been dependent on coastal-plain foods such as coconuts, taro and yams, but the falling sea level could have caused a fall in water tables of coastal lowlands, thereby impacting key crops (McCall1994; Nunn 2007). Marine dietary sources may also have been impacted by increased turbidity and exposure of coral reefs (McCall1994; Nunn 2007). Increased precipitation is believed to have caused highland erosion and lowland sedimentation (Nunn 2000). Nunn (2007) speculated that some islands may have had a reduction in food availability in the order of $80 \%$ over approximately a hundred years, and that increased fortifications around this time may indicate increased conflict over resources. Bridgman (1983) argued that increased climate volatility, including variability in trade winds, increased storminess and increased volcanic dust, may all have prevented voyaging in the Pacific during the LIA. McCall (1994) suggested that marginal areas and small islands of the Pacific would have been abandoned as they were more subject to the pressures of resource reduction and climate volatility, forcing populations back on to larger and better resourced islands, whilst Nunn (2000) argued that large coastal settlements would have been abandoned, with populations moving to fortifiable habitats such as caves and hilltops.

The effects of the LIA have been challenged by a number of researchers, including Allen (2006) and Spriggs (2010). Allen (2006) cited evidence for cooling in the Pacific during the Medieval Warm Period (named as such due to warming in the Northern Hemisphere) and found that the Palmyra coral record indicated a warm interval at 1300 $\mathrm{AD}$, but with nonetheless stormy and turbulent conditions. Allen (2006) also argued for intraregional variability, suggesting that the four climatic response regions identified by 
Salinger et al. (1995; 2001) may extend into antiquity and could be relevant to interpretations of climate volatility and change in the prehistoric Pacific. Spriggs (2010) suggested that human populations may have been prepared for and/or able to adapt to climatic conditions, due to ongoing instability including ENSO cycles. Regardless of its exact nature, climate volatility would have the potential to cause many of the diet and subsistence changes previously described. If we accept that there was intraregional variability in climate response (Allen 2006), this could provide an alternative explanation as to why dietary shifts occurred at different times in different places. These changes, in turn, may have impacted population growth through the region. However, this model only offers an explanation for the lack of a trend from 800 BP (Fig. 3). As previously noted, the models are not mutually exclusive and factors relating to both adaptation and climate change may be at play.

\section{Limitations}

Small sample sizes and infant underrepresentation were identified as two prominent factors that had the potential to influence model outcomes. With the negative growth sites (with potential infant/subadult underrepresentation), Teouma (where very few non-infant subadults were found), and Uripiv and Vao (small samples) removed, the temporal trend became significantly weaker $\left(r^{2}=0.07\right)$. The adaptation trend also weakened somewhat $\left(r^{2}=0.31\right)$, but notably the shape of the trend was unchanged. The reduced correlation is not caused by any one site, providing some assurance that they may indeed be representative. There are only two points (Sigatoka and Vao) between 500 and 2500 years since colonisation, and this study would benefit greatly from the addition of more data points during this period. Furthermore, additional data for islands and archipelagos with only a small number-or narrow chronological range-of sites would improve the interpretive power of this study.

The mid-points for the estimated years BP and period of colonisation for each site have been used to establish the chronological and years-since-colonisation trends. However, it is possible that the mid-point of either date range does not accurately reflect the mid-point of the burial usage or occupation period, as the site may have experienced more or less usage at various points in time or the skeletal sample may have been deposited over varying periods. Furthermore, the ranges for colonisation indicate a lack of certainty about the exact time of the event. As such, it is important to note that the estimates of RNPI are an average for the period over which the skeletal sample was deposited, and the colonisation mid-point indicates an estimate of the timing of the actual colonisation event. This may reduce the temporal precision of the results reported in this study.

\section{Conclusion}

There are two main interpretations of the data presented in this study. Firstly, the trend in population growth following colonisation indicates initially high population growth, followed by slowing and even declining growth, and finally a shift back 
to higher growth rates. These results favour the adaptation/resilience hypothesis. This trend is remarkably similar to that associated with the Neolithic Demographic Transition in mainland Southeast Asia (McFadden et al. 2018); however, it is only observed if the populations throughout the region are analysed as a whole. It is possible that the similarity in trends reflects consistency in population response (adaptation and resilience) to major changes, over time. This model supports the view that populations with good capacity for growth colonised the Pacific islands and archipelagos, but growth slowed and declined as they underwent a process of adaptation to their new environment, which involved changes in diet, subsistence strategy and landscape manipulation. Subsequent to successful adaptation, populations were again able to achieve higher growth, with improved understanding and management of resources. This is a simplified model and we would certainly anticipate that both adverse conditions - such as disease and natural disasters - and favourable ones would cause peaks and troughs on a smaller scale. Secondly, the lack of a temporal trend, particularly from $800 \mathrm{BP}$ onwards, may represent a high degree of heterogeneity in the impacts of the LIA on individual archipelagos, islands, and even localised populations. As such, there is also evidence for the validity of the temporal hypothesis. Arguably, both trends support Golson's (1972) assertion that at the time of European contact the island populations were in different stages of demographic oscillation.

\section{Conflict of interest}

There are no conflicts of interest.

\section{Availability of Data and Material}

All data used is included in this publication or is publicly available.

Acknowledgements This research was supported by an Australian Government Research Training Program (RTP) Scholarship, Australian Research Council; Grant number: FT 120100299; and Institute of Advanced Study (IAS), Durham University and The COFUND 'Durham International Fellowships for Research and Enterprise' scheme. We also thank Les O'Neill, Archaeology Programme, University of Otago, for creating Fig. 1.

Funding This research was supported by an Australian Government Research Training Program (RTP) Scholarship, Australian Research Council; Grant number: FT 120100299; and Institute of Advanced Study (IAS), Durham University and The COFUND 'Durham International Fellowships for Research and Enterprise' scheme.

Open Access This article is licensed under a Creative Commons Attribution 4.0 International License, which permits use, sharing, adaptation, distribution and reproduction in any medium or format, as long as you give appropriate credit to the original author(s) and the source, provide a link to the Creative Commons licence, and indicate if changes were made. The images or other third party material in this article are included in the article's Creative Commons licence, unless indicated otherwise in a credit line to the material. If material is not included in the article's Creative Commons licence and your intended use is not permitted by statutory regulation or exceeds the permitted use, you will need to obtain permission directly from the copyright holder. To view a copy of this licence, visit http://creativecommons.org/licen ses/by/4.0/. 


\section{References}

Allen, M. (2006). New ideas about late Holocene climate variability in the central Pacific. Current Anthropology, 47(3), 521-535.

Allen, M. (2014). Marquesan colonisation chronologies and post-colonisation interaction: Implications for Hawaiian origins and the 'Marquesan Homeland' hypothesis. Journal of Pacific Archaeology, $5,1-17$.

Anderson, A. (1984). The extinction of moa (Aves: Dinornithidae) in southern New Zealand. In P. S. Martin \& K. G. Klein (Eds.), Quaternary extinctions: A prehistoric revolution (pp. 728-740). Tucson: University of Arizona Press.

Anderson, A. (2002). Faunal collapse, landscape change and settlement history in Remote Oceania. World Archaeology, 33(3), 375-390.

Anderson, A., \& Sinoto, Y. (2002). New radiocarbon ages of colonization sites in east Polynesia. Asian Perspectives, 41, 242-257.

Antón, S., \& Steadman, D. (2003). Mortuary patterns in burial caves on Mangaia, Cook Islands. International Journal of Osteoarchaeology, 13(3), 132-146.

Arens, W. (1979). The man-eating myth: Anthropology and anthropophagy. New York: Oxford University Press.

Athens, J. S., Toggle, H. D., Ward, J. V., \& Welch, D. J. (2002). Avifaunal extinctions, vegetation change, and Polynesian impacts in prehistoric Hawai'i. Archaeology in Oceania, 37(2), 57-78.

Athens, J. S., Ward, J. V., \& Blinn, D. W. (2007). Vegetation history of Laysan Island, northwestern Hawaiian Islands. Pacific Science, 61(1), 17-37.

Athens, J. S., Rieth, T. M., \& Dye, T. S. (2014). A paleoenvironmental and archaeological model-based age estimate for the colonization of Hawai'i. American Antiquity, 79, 144-155.

Barber, I. (2004). Crops on the border: The growth of archaeological knowledge of Polynesian cultivation in New Zealand. In L. Furey \& S. Holdaway (Eds.), Change through time: 50 years of New Zealand archaeology. NZAA Monograph 26 (pp. 169-192). Auckland: NZAA.

Bedford, S., Spriggs, M., Buckley, H., Valentin, F., Regenvanu, R., \& Abong, M. (2010). Un cimetière de premier peuplement : Le site de Teouma, Sud Efate, Vanuatu/A cemetery of first settlement: Teouma, South Efate, Vanuatu. In C. Sand \& S. Bedford (Eds.), Lapita: Ancêtres océaniens/oceanic ancestors (pp. 140-161). Paris: Somogy éditions d'art/Musée du Quai Branly.

Bedford, S., Buckley, H., Valentin, F., Tayles, N., \& Longga, N. F. (2011). Lapita burials, a new Lapita cemetery and post-Lapita burials from Malakula, northern Vanuatu Southwest Pacific. Journal of Pacific Archaeology, 2(2), 26-48.

Bocquet-Appel, J.-P. (2002). Paleoanthropological traces of a Neolithic demographic transition. Current Anthropology, 43(4), 637-650.

Bocquet-Appel, J.-P. (2009). The demographic impact of the agricultural system in human history. Current Anthropology, 50(5), 657-660.

Bocquet-Appel, J.-P., \& Masset, C. (1982). Farewell to paleodemography. Journal of Human Evolution, 11(4), 321-333.

Bocquet-Appel, J.-P., \& Naji, S. (2006). Testing the hypothesis of a worldwide Neolithic demographic transition: Corroboration from American cemeteries. Current Anthropology, 47(2), 341-365.

Bowen, R. N. (1974). Mokapu: Its historical and archaeological past. In C. E. Snow (Ed.), Early Hawaiians: An initial study of skeletal remains from Mokapu, Oahu (pp. 129-148). Lexington: University Press of Kentucky.

Boyer, A. G. (2008). Extinction patterns in the avifauna of the Hawaiian Islands. Diversity and Distributions, 14(3), 509-517.

Brewis, A. A. (1995). Fertility and analogy in Pacific palaeodemography. Asian Perspectives, 1-20.

Brewis, A. A., Molloy, M. A., \& Sutton, D. G. (1990). Modeling the prehistoric Maori population. American Journal of Physical Anthropology, 81, 343-356.

Bridgman, H. A. (1983). Could climatic change have had an influence on the Polynesian migrations? Palaeogeography, Palaeoclimatology, Palaeoecology, 41, 193-206.

Buckley, H. R. (2000). Subadult health and disease in prehistoric Tonga, Polynesia. American Journal of Physical Anthropology, 113(4), 481-505.

Buckley, H. R. (2006). The predators within: Investigating the relationship between malaria and health in the prehistoric Pacific Islands. In M. F. Oxenham \& N. Tayles (Eds.), Bioarchaeology of Southeast Asia (pp. 309-332). Cambridge: Cambridge University Press. 
Buckley, H. R. (2016). Health and disease in the prehistoric Pacific islands. Oxford: British Archaeological Reports.

Buckley, H. R., Tayles, N., Halcrow, S. E., Robb, K., \& Fyfe, R. (2010). The people of Wairau Bar: A reexamination. Journal of Pacific Archaeology, 1, 1-20.

Buckley, H. R., Kinaston, R., Halcrow, S. E., Foster, A., Spriggs, M., \& Bedford, S. (2014). Scurvy in a tropical paradise? Evaluating the possibility of infant and adult vitamin $\mathrm{C}$ deficiency in the Lapita skeletal sample of Teouma, Vanuatu, Pacific islands. International Journal of Paleopathology, 5, $72-85$.

Buckley, H. R., \& Oxenham, M. F. (2016). Bioarchaeology in the Pacific islands: A temporal and geographical examination of nutritional and infectious disease. In M. Oxenham \& H. Buckley (Eds.), The Routledge handbook of bioarchaeology in Southeast Asia and the Pacific (pp. 363-388). New York: Taylor \& Francis.

Buikstra, J. E., Konigsberg, L. W., \& Bullington, J. (1986). Fertility and the development of agriculture in the prehistoric Midwest. American Antiquity, 51(3), 528-546.

Bulmer, S. (1975). Settlement and economy in prehistoric Papua New Guinea: A review of the archeological evidence. Journal de la Société des Océanistes, 31(46), 7-75.

Burke, A., Riel-Salvatore, J., \& Barton, C. M. (2018). Human response to habitat suitability during the Last Glacial Maximum in Western Europe. Journal of Quaternary Science, 33(3), 335-345.

Burley, D. V. (1998). Tongan archaeology and the Tongan past, 2850-150 BP. Journal of World Prehistory, 12(3), 337-392.

Burley, D., Edinborough, K., Weisler, M., \& Zhao, J. X. (2015). Bayesian modeling and chronological precision for Polynesian settlement of Tonga. PLOS ONE, 10(3), e0120795.

Burley, D. V., Horrocks, M., \& Weisler, M. I. (2020). Earliest evidence for pit cultivation provides insight on the nature of first Polynesian settlement. The Journal of Island and Coastal Archaeology, 15, $127-147$.

Campbell, M. (2011). The NRD Site. Vol. I: The Archaeology. CFG Heritage Ltd report to the Heritage $\mathrm{NZ}$ and Auckland International Airport Ltd.

CIA World Factbook. https://www.cia.gov/library/publications/the-world-factbook/fields/2097. html countryName $=\&$ countryCode $=\&$ regionCode $=$. .

Clark, J. T. (1988). Palaeodemography in Leeward Hawaii. Archaeology in Oceania, 23(1), 22-30.

Clark, G. A., Anderson, A., \& Wright, D. (2006). Human colonization of the Palau Islands, western Micronesia. Journal of Island and Coastal Archaeology, 1(2), 215-232.

Cochrane, E. E., Pietrusewsky, M., \& Douglas, M. T. (2004). Culturally modified human remains recovered from an earth-oven interment on Waya Island, Fiji. Archaeology in Oceania, 39, 54-59.

Collins, S. L. (1986). Osteological studies of human skeletal remains from the Keopu burial site. In T. L. Han, S. L. Collins, O. S. Clark, \& A. Garland (Eds.), Moe Kau a Ho'oilo: Hawaiian mortuary practices at Keopu, Kona, Hawai’i. Departmental Report Series, Report 86-1 (pp. 165-249). Honolulu: Department of Anthropology, B.P. Bishop Museum.

Commendador, A. S., Dudgeon, J. V., Finney, B. P., Fuller, B. T., \& Esh, K. S. (2013). A stable isotope $(\delta 13 \mathrm{C}$ and $\delta 15 \mathrm{~N})$ perspective on human diet on Rapa Nui (Easter Island) ca. AD 1400-1900. American Journal of Physical Anthropology, 152(2), 173-185.

Conte, E., \& Molle, G. (2014). Reinvestigating a key site for Polynesian prehistory: New results from the Hane dune site, Ua Huka (Marquesas). Archaeology in Oceania, 49, 121-136.

Cox, P. A., \& Banack, S. A. (1991). Islands, plants, and Polynesians: An introduction to Polynesian ethnobotany: Proceedings of a symposium. Portland: Dioscorides Press.

Davidson, J. M. (1984). The prehistory of New Zealand. Auckland: Longman Paul.

Davidson, J. M., \& Leach, B. F. (2001). The Strandlooper concept and economic naivety. In, Clark, G. R., Anderson, A. J., \& Vunidilo, T. (Eds.), The archaeology of Lapita dispersal in Oceania: Papers from the Fourth Lapita Conference, June 2000, Canberra, Australia. Terra Australis 17 (pp. 115123).Canberra: Centre for Archaeological Research, The Australian National University.

Degusta, D. (1999). Fijian cannibalism: Osteological evidence from Navatu. American Journal of Physical Anthropology, 110, 215-241.

Degusta, D. (2000). Fijian cannibalism and mortuary ritual: Bioarchaeological evidence from Vunda. International Journal of Osteoarchaeology, 10, 76-92.

Denham, T. P. (2003). Origins of agriculture at Kuk Swamp in the highlands of New Guinea. Science, 301, 189-193.

Diamond, J. M. (1977). Colonization cycles in man and beast. World Archaeology, 8(3), 249-261. 
Douglas, M. T., Pietrusewsky, M., \& Ikehara-Quebral, R. M. (1997). Skeletal biology of Apurguan: A precontact Chamorro site on Guam. American Journal of Physical Anthropology, 104(3), 291-313.

Dye, T. (1992). The South Point radiocarbon dates thirty years later. New Zealand Journal of Archaeology, 14(6), 89.

Field, J. S., \& Lape, P. V. (2010). Paleoclimates and the emergence of fortifications in the tropical Pacific islands. Journal of Anthropological Archaeology, 29(1), 113-124.

Field, J. S., Cochrane, E. E., \& Greenlee, D. M. (2009). Dietary change in Fijian prehistory: Isotopic analyses of human and animal skeletal material. Journal of Archaeological Science, 36(7), 1547-1556.

Fitzhugh, B., Gjesfjeld, E., Brown, W., Hudson, M. J., \& Shaw, J. D. (2016). Resilience and the population history of the Kuril Islands, Northwest Pacific: A study in complex human ecodynamics. Quaternary International, 419, 165-193.

Fitzpatrick, S. M. (2003). Early human burials in the western Pacific: Evidence for c. 3000 year old occupation on Palau. Antiquity, 77(298), 719-731.

Fitzpatrick, S. M., \& Jew, N. P. (2018). Radiocarbon dating and Bayesian modelling of one of Remote Oceania's oldest cemeteries at Chelechol ra Orrak Palau. Antiquity, 92(361), 149-164.

Galipaud, J. C., Kinaston, R., Halcrow, S., Foster, A., Harris, N., Simanjuntak, T., et al. (2016). The Pain Haka burial ground on Flores: Indonesian evidence for a shared Neolithic belief system in Southeast Asia. Antiquity, 90(354), 1505-1521.

Gill, G. W. (2000). Investigations of the 1981 Easter Island anthropological expedition. In C. M. Stevenson \& W. S. Ayres (Eds.), Easter Island archaeology: Research on early Rapanui culture. Easter Island Foundation: Los Osos.

Graves, M. (1991). Architectural and mortuary diversity in late prehistoric settlements at Tumon Bay, Guam. Micronesica, 242, 169-194.

Green, R. C. (1991). Near and Remote Oceania: Disestablishing 'Melanesia' in culture history. In A. Pawley (Ed.), Man and a half: Essays in Pacific anthropology and ethnobiology in honour of Ralph Bulmer (pp. 491-502). Auckland: The Polynesian Society.

Golson, J. (1972). The Pacific islands and their prehistoric inhabitants: Man in the Pacific Islands (pp. 5-33). Oxford: Oxford University Press.

Golson, J., Denham, T., Hughes, P., Swadling, P., \& Muke, J. (Eds.). (2017). Ten thousand years of cultivation at Kuk Swamp in the highlands of Papua New Guinea. Terra Australis, 46 46. Canberra: Australian National University Press.

Groube, L. (1971). Tonga, Lapita pottery and Polynesian origins. Journal of the Polynesian Society, 80, $278-314$.

Groube, L. (1993). Contradictions and malaria in Melanesian and Australian prehistory. In M. Spriggs (Ed.), A community of culture: A people and prehistory of the Pacific. Occasional papers in Prehistory, No. 21 (pp. 164-186). Canberra: The Australian National University.

Herrscher, E., Fenner, J., Valentin, F., Clark, G., Reepmeyer, C., Bouffandeau, L., \& André, G. (2018). Multi-isotopic analysis of first Polynesian diet (Talasiu, Tongatapu, Kingdom of Tonga). Journal of Archaeological Science Reports, 18, 308-317.

Holdaway, R., Allentoft, M., Jacomb, C., Oskam, C., Beavan, N., \& Bunce, M. (2014). An extremely lowdensity human population exterminated New Zealand moa. Nature Communications, 5, 5.

Holdaway, R. N., \& Jacomb, C. (2000). Rapid extinction of the moas (Aves: Dinorinthiformes): Model, test, and implications. Science, 287, 2250-2254.

Hudson, B. (2011). The NRD Site. Vol. II. The Koiwi. CFG Heritage Ltd report to the Heritage NZ and Auckland International Airport Ltd.

Hunt, T. L., \& Lipo, C. P. (2006). Late colonization of Easter Island. Science, 311, 1603-1606.

Irwin, G., Worthy, T. H., Best, S., Hawkins, S., Carpenter, J., \& Matararaba, S. (2011). Further investigations at the Naigani Lapita site (VL 21/5), Fiji: Excavation, radiocarbon dating and palaeofaunal extinction. Journal of Pacific Archaeology, 2, 66-78.

Jacomb, C., Holdaway, R., Allentoft, M., Bunce, M., Oskam, C., Walter, R., \& Brooks, E. (2014). Highprecision dating and ancient DNA profiling of moa (Aves: Dinornithiformes) eggshell documents a complex feature at Wairau Bar and refines the chronology of New Zealand settlement by Polynesians. Journal of Archaeological Science, 50, 24-30.

Jennings, W. (2011). The debate over Kai Tangata (Māori Cannibalism): New perspectives from the correspondence of the Marists. The Journal of the Polynesian Society, 120, 129-147.

Kinaston, R., Buckley, H., Valentin, F., Bedford, S., Spriggs, M., Hawkins, S., \& Herrscher, E. (2014). Lapita diet in Remote Oceania: New stable isotope evidence from the 3000-year-old Teouma site, Efate Island, Vanuatu. PLoS ONE, 9(3), e90376. 
Kirch, P. V. (1984). The evolution of the Polynesian chiefdoms. New York: Cambridge University Press.

Kirch, P. V. (1996). Late Holocene human-induced modifications to a central Polynesian island ecosystem. Proceedings of the National Academy of Sciences, 93(11), 5296-5300.

Kirch, P. V. (2000). On the road of the winds: An archaeological history of the Pacific islands before European contact. Berkeley: University of California Press.

Kirch, P. V. (2007). Paleodemography in Kahikinui, Maui. In P. V. Kirch \& J.-L. Rallu (Eds.), The growth and collapse of Pacific island societies: Archaeological and demographic perspectives (pp. 90-107). Honolulu: University of Hawaii Press.

Kirch, P. V. (2010). How chiefs became kings: Divine kingship and the rise of archaic states in ancient Hawai' $i$. Berkeley: University of California Press.

Kirch, P. V. (2017). Tangatatau rockshelter: The evolution of an eastern Polynesian socio-ecosystem. Monumenta Archaeologica. Los Angeles: Cotsen Institute of Archaeology Press.

Kirch, P., Steadman, D., Butler, V., Hather, J., \& Weisler, M. (1995). Prehistory and human ecology in Eastern Polynesia: Excavations at Tangatatau rockshelter, Mangaia, Cook Islands. Archaeology in Oceania, 30, 47-65.

Kirch, P. V., Flenley, J. R., Steadman, D. W., Lamont, F., \& Dawson, S. (1992). Prehistoric human impacts on an island ecosystem: Mangaia, Central Polynesia. Research and Exploration, 8, 166-179.

Kirch, P. V., Hartshorn, A. S., Chadwick, O. A., Vitousek, P. M., Sherrod, D. R., Coil, J., et al. (2004). Environment, agriculture, and settlement patterns in a marginal Polynesian landscape. Proceedings of the National Academy of Sciences, 101(26), 9936-9941.

Kirch, P. V., \& Hunt, T. L. (1997). Historical ecology in the Pacific Islands: Prehistoric environmental and landscape change. New Haven: Yale University Press.

Kirch, P. V., \& Rallu, J. L. (Eds.). (2007). The growth and collapse of Pacific island societies: Archaeological and demographic perspectives. Honolulu: University of Hawaii Press.

Kohler, T. A., Glaude, M. P., Bocquet-Appel, J.-P., \& Kemp, B. M. (2008). The Neolithic demographic transition in the US Southwest. American Antiquity, 73(4), 645-669.

Lambert, S. (1941). A doctor in paradise. Melbourne: J. M Dent \& Sons.

Leppard, T. P. (2016). Between deterministic and random process in prehistoric Pacific island abandonment. Journal of Pacific Archaeology, 7(2).

Lindenbaum, S. (2004). Thinking about cannibalism. Annual Review of Anthropology, 33, 475-498.

Lorrey, A., Fauchereau, N., Stanton, C., Chappell, P., Phipps, S., Mackintosh, A., et al. (2014). The Little Ice Age climate of New Zealand reconstructed from Southern Alps cirque glaciers: A synoptic type approach. Climate Dynamics, 42(11-12), 3039-3060.

McCall, G. (1994). Little Ice Age: Some proposals for Polynesia and Rapanui (Easter Island). Journal de la Société des Océanistes, 98, 99-104.

McCoy, M. D., \& Graves, M. W. (2010). The role of agricultural innovation on Pacific Islands: A case study from Hawai'i Island. World Archaeology, 42(1), 90-107.

McFadden, C., Buckley, H., Halcrow, S. E., \& Oxenham, M. F. (2018). Detection of temporospatially localized growth in ancient Southeast Asia using human skeletal remains. Journal of Archaeological Science, 98, 93-101.

McFadden, C., \& Oxenham, M. F. (2018). Rate of natural population increase as a paleodemographic measure of growth. Journal of Archaeological Science: Reports, 19, 352-356.

McFadden, C., \& Oxenham, M. F. (2019). The impacts of underenumeration and age estimation error on the D0-14/D ratio and palaeodemographic measures. Journal of Archaeological Science: Reports, 23, 57-61.

Manner, H. I., \& Thaman, R. R. (2013). Agriculture. In M. Rapaport (Ed.), The Pacific islands: Environment and society (Revised, pp. 341-354). Honolulu: University of Hawai'i Press.

Mcwethy, D. B., Wilmshurst, J. M., Whitlock, C., Wood, J. R., \& Mcglone, M. S. (2014). A high-resolution chronology of rapid forest transitions following Polynesian arrival in New Zealand. PLoS ONE, 9(11), e111328.

Morrison, A. E., \& Hunt, T. L. (2007). Human impacts on the nearshore environment: An archaeological case study from Kaua'i Hawaiian Islands. Pacific Science, 61(3), 325-345.

Neumann, K. (1992). Tradition and identity in Papua New Guinea: Some observations regarding Tami and Tolai. Oceania, 62(4), 295-316.

Nunn, P. D. (2000). Environmental catastrophe in the Pacific islands around AD 1300. Geoarchaeology: An International Journal, 15(7), 715-740.

Nunn, P. D. (2007). Holocene sea-level change and human response in Pacific Islands. Earth and Environmental Science Transactions of the Royal Society of Edinburgh, 98, 117-125. 
Obeyesekere, G. (2005). Cannibal talk: The man-eating myth and human sacrifice in the South Seas. Berkeley: University of California Press.

Petchey, F., Spriggs, M., Bedford, S., Valentin, F., \& Buckley, H. (2014). Radiocarbon dating of burials from the Teouma Lapita cemetery, Efate, Vanuatu. Journal of Archaeological Science, 50, 227-242.

Petchey, F., Spriggs, M., Bedford, S., \& Valentin, F. (2015). The chronology of occupation at Teouma, Vanuatu: Use of a modified chronometric hygiene protocol and Bayesian modeling to evaluate midden remains. Journal of Archaeological Science: Reports, 4, 95-105.

Petchey, F., Clark, G., Winter, O., O’Day, P., \& Litster, M. (2016). Colonisation of remote Oceania: New dates for the Bapot-1 site in the Mariana Islands. Archaeology in Oceania, 52(2), 108-126.

Perry, G. L., Wheeler, A. B., Wood, J. R., \& Wilmshurst, J. M. (2014). A high-precision chronology for the rapid extinction of New Zealand moa (Aves, Dinornithiformes). Quaternary Science Reviews, $105,126-135$.

Pietrusewsky, M. (1976). Prehistoric human skeletal remains from Papua New Guinea and the Marquesas. Asian and Pacific Archaeology Series No. 7. Honolulu: Social Sciences Linguistic Institute, University of Hawaii.

Pietrusewsky, M., \& Douglas, M. T. (1994). An osteological assessment of health and disease in precontact and historic (1778) Hawaii. In C. S. Larsen \& G. R. Milner (Eds.), In the wake of contact: Biological responses to conquest (pp. 179-196). New York: Wiley-Liss.

Pietrusewsky, M., Douglas, M.T., Kalima, P.A., \& Ikehara, R.M. (1991). Human skeletal and dental remains from the Honokahua burial site, Land of Honokahua, Lahaina District of Maui, Hawai'i. PHRI Report 246-041091 prepared for Kapalua Land Company, Ltd, Kahului, Maui.

Pietrusewsky, M., Douglas, M. T., \& Ikehara-Quebral, R. M. (1994). The human osteology of the Sigatoka dune burials (Site VL 16/1), Viti Levu, Fiji Islands. Unpublished report, University of Hawaii.

Pietrusewsky, M., Douglas, M. T., \& Ikehara-Quebral, R. M. (1997). An assessment of health and disease in the prehistoric inhabitants of the Mariana Islands. American Journal of Physical Anthropology, 104(3), 315-342.

Pietrusewsky, M., Douglas, M. T., Cochrane, E. E., \& Reinke, S. (2007). Cultural modifications in an adolescent earth-oven interment from Fiji: Sorting out mortuary practice. The Journal of Island and Coastal Archaeology, 2, 44-71.

Pietrusewsky, M., Douglas, M. T., \& Ikehara-Quebral, R. M. (2017). Skeletal and dental health: The bioarchaeology of the human skeletons from the Sigatoka sand dunes site, VL 16/1, Viti Levu, Fiji. Journal of Pacific Archaeology, 8(2).

Richards, M. P., West, E., Rolett, B., \& Dobney, K. (2009). Isotope analysis of human and animal diets from the Hanamiai archaeological site (French Polynesia). Archaeology in Oceania, 44(1), 29-37.

Sahlins, M. D. (1958). Social stratification in Polynesia. Seattle: University of Washington Press.

Salinger, M. J., Basher, R. E., Fitzharris, B. B., Hay, J. E., Jones, P. D., MacVeigh, J. P., \& SchmidelyLeleu, I. (1995). Climate trends in the South-west Pacific. International Journal of Climatology, 15(3), 285-302.

Salinger, M. J., Renwick, J. A., \& Mullan, A. B. (2001). Interdecadal Pacific oscillation and south Pacific climate. International Journal of Climatology, 21(14), 1705-1721.

Sayers, E. (1943). Malaria in the South Pacific. Wellington: E.V. Paul.

Scott, R. M., Buckley, H. R., Spriggs, M., Valentin, F., \& Bedford, S. (2010). Identification of the first reported Lapita cremation in the Pacific Islands using archaeological, forensic and contemporary burning evidence. Journal of Archaeological Science, 37, 901-909.

Snow, C. E. (1974). Early Hawaiians: An initial study of skeletal remains from Mokapu, Oahu. Lexington: University Press of Kentucky.

Spriggs, M. (2010). Geomorphic and archaeological consequences of human arrival and agricultural expansion on Pacific islands: A reconsideration after 30 years of debate. In, Haberle, S., Stevenson, J., \& Prebble, M. (Eds.) Altered ecologies: Fire, climate and human influence on terrestrial landscapes. Terra Australis (pp. 239-252). Canberra: Australian National University.

Spriggs, M., \& Anderson, A. (1993). Late colonization of East Polynesia. Antiquity, 67, 200-217.

Stantis, C., Kinaston, R. L., Richards, M. P., Davidson, J. M., \& Buckley, H. R. (2015). Assessing human diet and movement in the Tongan maritime chiefdom using isotopic analyses. PLoS ONE, 10(3), e0123156.

Steadman, D. W. (1995). Prehistoric extinctions of Pacific Island birds: Biodiversity meets zooarchaeology. Science, 267, 1123-1130. 
Steadman, D. W. (1997). Human-caused extinction of birds. In M. L. Reaka-Kudla, D. E. Wilson, \& E. O. Wilson (Eds.), Biodiversity II: Understanding and protecting our biological resources (pp. 139-161). Washington: Joseph Henry Press.

Steadman, D. W. (2006). Extinction and biogeography of tropical Pacific birds. Chicago: University of Chicago Press.

Sutton, D. G., \& Molloy, M. A. (1989). Deconstructing Pacific palaeodemography: A critique of density dependent causality. Archaeology in Oceania, 24(1), 31-36.

Swift, J. A., Roberts, P., Boivin, N., \& Kirch, P. V. (2018). Restructuring of nutrient flows in island ecosystems following human colonization evidenced by isotopic analysis of commensal rats. Proceedings of the National Academy of Sciences, 115(25), 6392-6397.

Tallavaara, M., \& Seppä, H. (2012). Did the mid-Holocene environmental changes cause the boom and bust of hunter-gatherer population size in eastern Fennoscandia? The Holocene, 22(2), 215-225.

Tallavaara, M., Luoto, M., Korhonen, N., Järvinen, H., \& Seppä, H. (2015). Human population dynamics in Europe over the Last Glacial Maximum. Proceedings of the National Academy of Sciences, $112(27), 8232-8237$.

Taylor, T. (2004). The buried soul: How humans invented death. Boston: Beacon Press.

Taylor, T. (2018). Uniform to unique: Cannibals, vampires and non-paradigmatic data. In Drauschke, J., Kislinger, E., Kühtreiber, K., Kühtreiber, T., Scharrer-Liška, G., \& Vida, T. (Eds.), Lebenswelten zwischen Archäologie und Geschichte: Fetschrift für Falko Daim zu seinem 65. Geburtstag (pp. 411-421). Mainz: Verlag des Römisch-Germanischen Zentralmuseums.

Thomas, N. (1990). Marquesan societies: Inequality and political transformation in eastern Polynesia. Oxford: Oxford University Press.

Tromp, M., Matisoo-Smith, E., Kinaston, R., Bedford, S., Spriggs, M., \& Buckley, H. (2020). Exploitation and utilization of tropical rainforests indicated in dental calculus of ancient Oceanic Lapita culture colonists. Nature Human Behaviour, 1-7.

Tuljapurkar, S., Lee, C. T., \& Figgs, M. (2007). Demography and food in early Polynesia. In P. V. Kirch \& J.-L. Rallu (Eds.), The growth, regulation, and collapse of island societies: Archaeological and demographic perspectives from the Pacific (pp. 35-51). Honolulu: University of Hawaii Press.

Valentin, F., Herrscher, E., Bedford, S., Spriggs, M., \& Buckley, H. (2014). Evidence for social and cultural change in central Vanuatu between 3000 and 2000 BP: Comparing funerary and dietary patterns of the first and later generations at Teouma, Efate. The Journal of Island and Coastal Archaeology, 9(3), 381-399.

Walter, R., \& Sheppard, P. J. (2017). The archaeology of the Solomon Islands. Honolulu: University of Hawai'i Press.

Weisler, M. I. (1998). Hard evidence for prehistoric interaction in Polynesia. Current Anthropology, 39, $521-532$.

Weisler, M. I., \& Walter, R. (2017). East Polynesian connectivity. In T. Hodos (Ed.), The Routledge handbook of archaeology and globalization (pp. 369-386). London: Taylor \& Francis.

Whitehead, N. E., Devine, S. D., \& Leach, B. F. (1986). Electron spin resonance dating of human teeth from the Namu burial ground, Taumako, Solomon Islands. New Zealand Journal of Geology and Geophysics, 29(3), 359-361.

Wilmshurst, J. M., Anderson, A. J., Higham, T. F. G., \& Worthy, T. H. (2008). Dating the late prehistoric dispersal of Polynesians to New Zealand using the commensal Pacific rat. Proceedings of the National Academy of Sciences, 105, 7676-7680.

Publisher's Note Springer Nature remains neutral with regard to jurisdictional claims in published maps and institutional affiliations. 


\section{Authors and Affiliations}

\section{Clare McFadden ${ }^{1}$ D $\cdot$ Richard Walter $^{2}$ (D) Hallie Buckley ${ }^{3}$ (D)} Marc F. Oxenham ${ }^{1,4}$ (D)

1 School of Archaeology and Anthropology, The Australian National University, Canberra, Australia

2 Department of Anthropology and Archaeology, University of Otago, Dunedin, New Zealand

3 Department of Anatomy, University of Otago, Dunedin, New Zealand

4 Department of Archaeology, University of Aberdeen, Aberdeen, Scotland 